Editorial

\section{Convalescent plasma: a valid option in the treatment of COVID-19?}

\author{
Genjiao Liu ${ }^{1}$ and Shuang $\mathrm{Li}^{2 *}$ \\ ${ }^{1}$ Health Community of Lianhua, Jiangxi, China \\ ${ }^{2}$ Health Community of Chenghua, Sichuan, China
}

In the late of 2019, there is an outbreak of novel coronavirus disease (COVID-19) in Wuhan, China. The patients appear respiratory symptoms, fever, and cough, shortness of breath and breathing difficulties. In more severe cases, infection can cause pneumonia, severe acute respiratory syndrome, kidney failure and even death. A novel coronavirus (nCoV) is a new strain that has not been previously identified in humans and is transmitted mostly via droplets or contact. People of all ages are susceptible to the virus. Up to the middle of February 2020, the number of infected persons in China is over 65,000 . The case fatality rate was $2.38 \%$, and elderly men with underlying diseases were at a higher risk of death [1].

In terms of treatment, COVID-19 patients with mild symptoms received oseltamivir or/and intravenous antibiotics, while severe patients also received oxygen inhalation, mechanical ventilation. The $\mathrm{nCoV}$ is a new emerging virus that has not been previously identified in humans, there is no specific drugs or vaccine. Plasma from recovery patients containing $\mathrm{nCoV}$-specific antibodies was considered as a feasible therapeutic option. This type of therapeutic intervention is not novel, as it has been used to deal with most life threatening epidemics. When antiviral drugs were not effectiv, convalescent plasma has been used as a valid option in treatment with some several infectious diseases, such as (severe acute respiratory syndrome) SARS, (influenza A/H5N1) A/H5N1 flu, Ebola, etc..., [2].

But the efficacy of convalescent plasma treatment for severe infectious diseases is still controversial. A mate analysis of the effectives of convalescent plasma therapy for SARS showed that the early treatment with plasma might be beneficial [3]. Besides, a total of 84 Ebola virus disease patients who were treated with convalescent plasma showed no significant improvement in survival. After clinical evaluation of convalescent plasma for ebola virus disease in Guinea, van Griensven, et al. provide additional data showing that the dose of neutralizing antibodies in the donations was low and that there was no apparent association between the dose of neutralizing antibodies and human survival [4].
More Information

*Address for Correspondence: Shuang Li, Health Community of Chenghua, Sichuan, China, Tel: +86 17600695596; Email: alyssa@bjmu.edu.cn; Amber1333@163.com

Submitted: 19 February 2020

Approved: 25 February 2020

Published: 25 February 2020

How to cite this article: Liu G, Li S. Convalescent plasma: a valid option in the treatment of COVID-19? Insights Clin Cell Immunol. 2020; 4: 001-002.

DOI: 10.29328/journal.icci.1001012

Copyright: ( 2020 Liu G, et al. This is an open access article distributed under the Creative Commons Attribution License, which permits unrestricted use, distribution, and reproduction in any medium, provided the original work is properly cited.

\section{W) Check for updates}

(1) OPEn Access

Furthermore, other research showed that the convalescent plasma specimens from survivors of Ebola virus infection showed low neutralizing activity against Ebola virus [5]. This may explain why the plasma treatment for Ebola infected patients is not effective. A case report that an influenza A (H5N1) virus infected male after received convalescent plasma from a patient who had recovered from H5N1 infection, the patient's viral load was reduced during the first 8 hours and was undetectable within 32 hours [6]. In addition, with double blind, randomized, placebo controlled trials, influenza A infected adults were randomly assigned to receive standard care plus either convalescent plasma infusion or saline placebo, but when administered alongside standard care plasma treatment was not superior to placebo for adults hospitalized with influenza A infection $[7,8]$. To sum up, there are still some issues to consider for the effectiveness of plasma therapy. For example, screen out potential donors with high neutralising antibody titres; the curative rates in plasma treatment trials will be influenced not only by patients' risk factors but also by the specific supportive care offered by clinical hospitals.

Now convalescent plasma treatments enter clinical practice with severe COVID-19 patients in China. Even it is reported that after infusion the plasma patients' clinical signs and symptoms were improved significantly [9], due to the lack of large-scale, randomized, well-designed clinical trials, we tend to consider convalescent plasma treatment is an experiential therapy. 


\section{References}

1. Zhonghua L, Xing BX, Za Z. An Update on the Epidemiological Characteristics of Novel Coronavirus pneumonia (COVID-19). 2020; 41:139-144.

PubMed: https://www.ncbi.nlm.nih.gov/pubmed/32057211

2. Giuseppe M, Stefania V, Simonetta $P$, Giuseppina F, Liviana $C$, et al. Convalescent plasma: new evidence for an old therapeutic tool? Blood Transfus. 2016; 14: 152-157.

PubMed: https://www.ncbi.nlm.nih.gov/pubmed/26674811

3. Mair JJ, Saavedra CM, Baillie JK, Cleary P, Khaw FM, et al. The effectiveness of convalescent plasma and hyperimmune immunoglobulin for the treatment of severe acute respiratory infections of viral etiology: a systematic review and exploratory meta-analysis. J Infect Dis. 2015; 211: 80-90.

PubMed: https://www.ncbi.nlm.nih.gov/pubmed/25030060

4. Van GJ, Edwards T, de LX, Semple MG, Gallian P, et al. Evaluation of convalescent plasma for Ebola virus disease in Guinea. N Engl J Med. 2016; 374: 33-42.

PubMed: https://www.ncbi.nlm.nih.gov/pubmed/26735992
5. Luczkowiak J, Lasala F, Mora-RM, Arribas JR, Delgado R. Broad Neutralizing Activity Against Ebolaviruses Lacking the Mucin-Like Domain in Convalescent Plasma Specimens From Patients With Ebola Virus Disease. J Infect Dis. 2018; 218: S574-S581. PubMed: https://www.ncbi.nlm.nih.gov/pubmed/29939289

6. Zhou B, Zhong N, Guan Y. Treatment with convalescent plasma for influenza A (H5N1) infection. N Engl J Med. 2007; 357: 1450-1451. PubMed: https://www.ncbi.nlm.nih.gov/pubmed/17914053

7. Davey RT Jr, Fernández-CE, Markowitz N, Pett $S$, Babiker AG, et al. Anti-influenza hyperimmune intravenous immunoglobulin for adults with influenza A or B infection (FLU-IVIG): a double-blind, randomised, placebo-controlled trial. Lancet Respir Med. 2019; 7: 951-963. PubMed: https://www.ncbi.nlm.nih.gov/pubmed/31582358

8. Beigel JH, Aga E, Elie-TMC, Cho J, Tebas $P$, et al. Anti-influenza immune plasma for the treatment of patients with severe influenza $A$ : a randomised, double-blind, phase 3 trial. Lancet Respir Med. 2019. PubMed: https://www.ncbi.nlm.nih.gov/pubmed/31582360

9. http://www.xinhuanet.com/english/2020-02/14/c_138783294.htm 